\title{
KEMAMPUAN CALON PENDIDIK DALAM MEMANFAATKAN TEKNOLOGI KOMPUTER UNTUK MENGEMBANGKAN MULTIMEDIA PEMBELAJARAN MATEMATIKA
}

\author{
Niluh Sulistyani \\ Fakultas Keguruan dan Ilmu Pendidikan, Universitas Sanata Dharma \\ Email: niluh@usd.ac.id
}

\begin{abstract}
This study was aimed to describe ability of prospective student educators in using computer technology to develop mathematics learning multimedia. The ability was used to develop Power Point multimedia and Adobe Flash multimedia. This study was descriptive research with 27 prospective student educators as a subject. Researcher was main instrument assisted product evaluation rubric and questionnaire. The result showed that the average of ability of prospective student educators in using computer technology was in good category. The average score were 77,59 in using Power Point multimedia and 74,54 in using Adobe Flash multimedia. The ability was sufficiently to be used in learning and teaching. From the product analyzed and questionnaire, we found that the ability were not maximal because there were many tools untapped primarily in Adobe Flash. Unfamiliar yet in used also became a factor that affected the ability of prospective educators in using computer technology.
\end{abstract}

Keywords: The ability in using computer technology, mathematics learning multimedia, prospective educators

\section{PENDAhuluan}

Indonesia saat ini sedang mengalami perubahan menuju era digital di mana informasi menyebar begitu cepat dengan bantuan teknologi yang ada. Kecanggihan teknologi menimbulkan dampak positif maupun negatif tergantung dari bagaimana menyikapi atau memanfaatkan teknologi dan isi informasi yang disebarkan. Bagi anakanak di bawah umur diperlukan peran dan pendampingan orang dewasa baik orang tua maupun guru selaku pendidik agar tidak mengkonsumsi informasi yang dilarang. Sedangkan untuk menyikapi perkembangan yang ada, sangatlah baik jika teknologi dapat dimanfaatkan secara bijak misalnya digunakan sebagai sarana edukasi.

Salah satu bentuk pemanfaatan kecanggihan teknologi adalah dengan menciptakan atau memanfaatkan teknologi sebagai media pembelajaran yang menarik dan lebih menyenangkan bagi siswa. Media merupakan segala sesuatu yang dapat digunakan untuk menyalurkan pesan dari pengirim ke penerima sehingga dapat merangsang pikiran, perasaan, perhatian, dan minat serta perhatian siswa sedemikian rupa sehingga proses belajar dapat terjadi (Sadiman, dkk, 2009:7). 
Kemampuan Calon Pendidik dalam Memanfaatkan Teknologi Komputer untuk Mengembangkan Multimedia Pembelajaran Matematika

Niluh Sulistyani

Media dalam proses belajar mengajar dimaksudkan untuk mempermudah penyampaian pesan, informasi, atau materi pelajaran kepada siswa. Terkait peran penting media dalam pembelajaran, UndangUndang Republik Indonesia Nomor 14 Tahun 2005 Tentang Guru dan Dosen pasal 10 menegaskan bahwa guru harus memiliki kompetensi pedagogik, kepribadian, sosial, dan profesional. Salah satu unsur kompetensi pedagogik adalah guru mampu mengembangkan dan memanfaatkan media dan sumber belajar. Mengingat pentingnya media dalam pembelajaran, guru selaku pendidik diharapkan mampu untuk mengembangkan dan memanfaatkan media pembelajaran.

Pada kenyataannya media pembelajaran termasuk juga multimedia masih sering terabaikan dengan berbagai alasan, antara lain: terbatasnya waktu untuk membuat persiapan mengajar, sulit mencari media yang tepat, tidak tersedianya biaya, dan lainlain. Hal ini sebenarnya tidak perlu terjadi jika setiap tenaga pendidik telah mempunyai pengetahuan dan keterampilan mengenai media pembelajaran (Mulyanta \& Leong, 2013). Ketika yang dikembangkan terdiri dari berbagai kombinasi dari media berbasis komputer dan sistem komunikasi dalam bentuk teks, grafik, audio, video, dan sebagai maka media ini disebut sebagai multimedia pembelajaran (Munir, 2015: 2).

Seperti halnya media pembelajaran, penggunaan multimedia dalam pembelajaran salah satunya bertujuan untuk mempermudah komunikasi dan memperkuat penyampaian informasi dengan menggunakan berbagai jenis media yang digunakan (teks, suara, grafik, animasi, dan video) (Munir, 2015: 16). Walaupun sudah masuk era digital, masih banyak buku yang menyatakan bahwa guru belum dapat memantaatkan teknologi untuk menciptakan multimedia pembelajaran. Di sinilah diperlukan peran perguruan tinggi untuk menciptakan calon pendidik yang profesional dan kompeten termasuk juga dalam mengembangkan multimedia pembelajaran.

Perkuliahan media komputer dalam pembelajaran matematika merupakan perkuliahan yang bertujuan untuk memfasilitasi mahasiswa dalam memanfaatkan teknologi komputer untuk membangun paket pembelajaran dalam hal ini adalah media pembelajaran berbasis multimedia komputer. Multimedia yang diciptakan mahasiswa diharapkan tidak sekedar syarat untuk lulus, namun tetap pada esensinya yaitu dapat digunakan untuk menyalurkan pesan dari pengirim dalam hal ini adalah pendidik ke penerima yaitu 
peserta didik sehingga dapat merangsang pikiran, perasaan, dan minat peserta didik serta perhatian sedemikian rupa sehingga proses belajar dapat terjadi dengan baik (Sadiman dkk, 2009: 7).

Dalam perkuliahan media komputer, kemampuan mahasiswa dalam mengembangkan multimedia pembelajaran merupakan salah satu faktor penentu keberhasilan peserta didik dalam mencapai kompetensi yang diharapkan (Mulyanta \& Leong, 2013: 2). Salah satu kemampuan tersebut adalah terampil dalam memanfaatkan teknologi komputer yaitu dengan cara dapat memanfaatkan berbagai macam fasilitas dalam hal ini dibatasi pada program Ms. Power point dan Adobe Flash.

Pengukuran kemampuan dalam memanfaatkan teknologi dapat dilakukan melalui proses review software yang dilihat dari segi teknis dan aspek pendidikannya. Review teknis dikonduksi dari penilain aspek software seperti ketahanan dan kehandalan dalam kondisi normal, desain tampilan, kemudahan penggunaan, petunjuk, kualitas warna, suara, grafis, dan animasi. Review dari aspek pendidikan menyatakan penilaian tentang nilai software sebagai alat pengajaran/pembelajaran, misalnya keakuratan isi, tingkat kesulitan sesuai dengan audien, dan perangkat lunak sesuai dengan tujuan yang dinyatakannya (Bayram \& Nous, 2004:23).

Dari hasil penelitian yang dilakukan oleh Andayani, dkk (2007) disimpulkan bahwa terjadi peningkatan kemampuan mahasiswa dalam penguasaan teknologi pembelajaran melalui tugas pembuatan media berbasis komputer. Melihat latar belakang dan pertimbangan di atas dilakukan penelitian yang bertujuan untuk mendeskripsikan kemampuan mahasiswa calon pendidik dalam memanfaatkan teknologi komputer untuk mengembangkan multimedia pembelajaran matematika.

Adapun manfaat yang diharapkan adalah (1) memberikan informasi, wawasan, dan pengetahuan terkait dengan kemampuan calon dosen dalam memanfaatkan teknologi komputer untuk mengembangkan multimedia pembelajaran, (2) dapat menjadi salah satu pertimbangan dalam mengembangkan pembelajaran yang lebih optimal dengan mempertimbangkan kompetensi yang dibutuhkan dalam dunia kerja khususnya dalam menciptakan multimedia pembelajaran, dan (3) memfasilitasi calon pendidik untuk mengembangkan kemampuan kognitif, afektif, dan psikomotorik dalam proses menciptakan multimedia pmbelajaran matematika. 
Kemampuan Calon Pendidik dalam Memanfaatkan Teknologi Komputer untuk Mengembangkan Multimedia Pembelajaran Matematika

Niluh Sulistyani

\section{METODE PENELITIAN}

Sesuai tujuan, penelitian ini merupakan penelitian deskriptif kualitatif di mana peneliti bertindak sebagai instrumen utama. Subjek penelitian adalah mahasiswa kelas A semester genap tahun ajaran 2015/2016 yang mengampu mata kuliah Media Komputer dalam Pembelajaran Matematika yang terdiri dari 27 mahasiswa. Objek penelitian meliputi kemampuan calon pendidik dalam memanfaatkan teknologi komputer.

Instrumen yang digunakan dalam penelitian ini adalah pedoman penskoran produk atas multimedia pembelajaran matematika yang dikembangkan dan kuesioner terbuka. Dalam pedoman penskoran produk diambil penilaian yang melibatkan dua aspek yaitu penilaian teknis dan materi (Bayram \& Nous, 2004: 23). Kriteria penilaian aspek teknis adalah 1) reliabilitas, 2) tampilan desain, dan 3) kemudahan penggunaan. Kriteria penilaian untuk aspek materi ditinjau dari isi dan bahasa. Total indikator untuk menilai kemampuan mahasiswa memanfaatkan teknologi adalah 15 indikator di mana masing-masing indikator mempunyai rentang skor $1-10$. Kuesioner terbuka digunakan untuk mendukung data hasil penilaian produk terhadap multimedia yang dikembangkan. Sebelum digunakan untuk pengambilan data, semua instrumen sudah divalidasi dan dinyatakan valid oleh dua rekan sejawat.

Untuk memperoleh keabsahan data pada penilitian ini digunakan analisis triangulasi teknik metodologis di mana digunakan dua instrumen untuk mengukur data yang sama, yaitu kemampuan memanfaatkan teknologi komputer.

Pedoman penskoran produk untuk mengukur kemampuan memanfaatkan teknologi dianalisis secara deskriptif. Skor yang diperoleh masing-masing media dijumlahkan kemudian dicari rata-ratanya terhadap semua media yang dikembangkan mahasiswa. Karena dalam penelitian ini mahasiswa mengembangkan dua media yaitu media Power Point dan Flash maka akan diperoleh dua rata-rata kemampuan mahasiswa dalam memanfaatkan teknologi, yaitu kemampuan memanfaatkan teknologi pada media power point dan flash. Rata-rata yang diperoleh kemudian dikelompokkan dalam tabel kategori berikut.

Tabel 1. Pengkategorian rata-rata kemampuan memanfaatkan teknologi komputer

\begin{tabular}{l|l}
\hline Nilai & Kategori \\
\hline $80-100$ & Sangat Baik \\
\hline $66-79$ & Baik \\
\hline $56-65$ & Cukup Baik \\
\hline $40-55$ & Kurang Baik \\
\hline $0-39$ & Tidak Baik \\
\hline
\end{tabular}

(Arikunto \& Jabar, 2009) 


\begin{abstract}
Selain dicari kategori juga dideskripsikan kemampuan yang rata-rata mahasiswa baik dari segi teknis maupun materi untuk memperjelas kategori yang diperoleh.

Kuesioner terbuka dianalisis secara kualitatif yang terdiri dari langkah reduksi data, penyajian data, dan penarikan kesimpulan. Saran dan komentar dari mahasiswa triangulasi untuk selanjutnya diperoleh kesimpulan.
\end{abstract}

\section{HASIL DAN PEMBAHASAN}

Hasil penelitian dari penilaian produk terhadap multimedia pembelajaran berbasis Power Point dan Adobe Flash menggunakan pedoman penskoran menunjukkan bahwa rata-rata kemampuan mahasiswa calon pendidik dalam memanfaatkan teknologi komputer dalam kategori baik, di mana ratarata skor yang diperoleh adalah 77,59 untuk media Power Point dan 74,54 untuk Adobe Flash. Perbedaan kemampuan ini dipengaruhi oleh perbedaan karakter dalam program Ms. Power Point dan Adobe Flash. Karena perbedaan karakter inilah maka pendeskripsian kemampuan memanfaatkan teknologi komputer calon pendidik dilakukan secara terpisah.

Pada produk multimedia menggunakan program Ms. Power Point skor yang diperoleh mendeskripsikan bahwa masih ada beberapa kekurangan/kelemahan yang dialami mahasiswa sebagai calon pendidik.
Kekurangan tersebut diantaranya menyangkut reliabilitas di mana ada bagian program yang berjalan tidak sempurna misalnya VBA (visual basic application) yaitu sebesar $15,38 \%$, kelemahan dalam hal tampilan misalnya berkaitan dengan bagaimana memadukan berbagai macam tools/fitur/aplikasi yang digunakan, penggunaan animasi, serta kualitas komponen yang digunakan. Kelemahan pada aspek ini sebesar $21,53 \%$. Dari segi materi kebanyakan multimedia mengalami kekurangan dalam hal ketepatan alur berpikir saat penyajian materi. Kekurangan dari segi ini adalah sebesar 16,67\%.

Maksud dari reliabilitas dalam penelitian ini adalah program berjalan dengan baik sehingga toleransi kesalahan operasi tinggi seperti yang diungkapkan oleh (Bayram \& Nous, 2004: 22). Sedangkan kelemahan yang dialami oleh calon pendidik adalah ketidaksempurnaan jalannya program misalnya penskoran dan proses input jawaban latihan soal menggunakan visual basic application. Hal ini dapat dilihat dalam Gambar 1. di bawah ini.

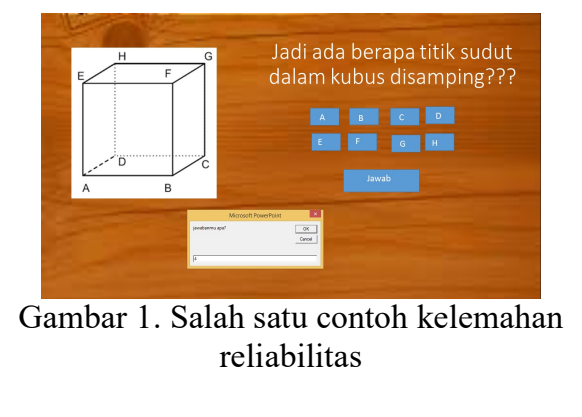


Kemampuan Calon Pendidik dalam Memanfaatkan Teknologi Komputer untuk Mengembangkan Multimedia Pembelajaran Matematika

Niluh Sulistyani

Kriteria tampilan desain meliputi (1) pemilihan komponen multimedia sudah tepat, (2) memadukan berbagai macam tools/fitur/aplikasi, (3) kesesuaian ilustrasi dengan materi, (4) penggunaan animasi efektif dan efisien, dan (5) kualitas teks, gambar, animasi, dan suara (Bayram \& Nous, 2004: 22). Kekurangan yang dijumpai pada kriteria ini diantaranya adalah (1) tidak adanya animasi sehingga multimedia terkesan monoton, (2) ukuran teks tidak proporsional sehigga sulit dibaca, (3) keterangan pada gambar tidak proporsional, bahkan (4) ada yang tanpa membubuhkan keterangan pada gambar padahal hal tersebut sangat diperlukan.

Kriteria terakhir pada aspek teknis adalah kemudahan penggunaan. Kebanyakan multimedia yang diciptakan tidak terlalu bermasalahan dalam kriteria ini.

Selain aspek teknik juga dilakukan penilaian terhadap aspek materi yaitu melihat multimedia sebagai salah satu bagian dalam unsur pedagogi yaitu sebagai salah satu sumber dalam pembelajaran (Bayram \& Nous, 2004: 22). Penilaian aspek ini dilihat dari segi isi yaitu (1) keakuratan/kebenaran isi, (2) kesesuaian isi dengan tujuan, (3) ketepatan alur berpikir, dan (4) kesesuaian isi dengan tingkat berpikir audiens serta melihat kriteria bahasa yaitu tidak menimbulkan penafsiran ganda dan bahasa sederhana/mudah dipahami. Kelemahan media dalam kriteria ini sebagian besar adalah alur berpikir yang tidak sesuai da nisi tidak sesuai dengan tingkat berpikir audiens.

Pada multimedia Adobe Flash terjadi penurunan kemampuan calon pendidik dalam memanfaatkan teknologi komputer. Penurunan ini disebabkan karena perbedaan tingkat kesulitan pemanfaatan dan pengoperasian Power Point dan Adobe Flash. Banyak mahasiswa yang baru mengenal Adobe Flash sehingga mereka memerlukan banyak waktu untuk terbiasa menggunakan Flash.

Kesulitan dalam multimedia Adobe Flash pada dasarnya hampir sama dengan kesulitan yang dijumpai dalam Power Point. Kesulitan reliabilitas yang disebabkan kurang sempurnanya program berjalan sebesar $18,75 \%$, kesulitan dari segi tampilan (termasuk memanfaatkan berbagai macam tools/fitur/aplikasi) sebesar 23,5\%, dan kesulitan dari segi materi terutama alur berpikir adalah sebesar $14,58 \%$.

Segi teknis tertama dalam kriteria tampilan menjadi kesulitan terbesar di antara kesulitan lainnya. Hal ini disebabkan karena kerumitan dalam menciptkakan animasi dalam program Adobe Flash terutama pemanfaatan tweens. Contoh 
ketidaksesuaian isi sekaligus tampilan dapat dilihat pada Gambar 2. berikut.

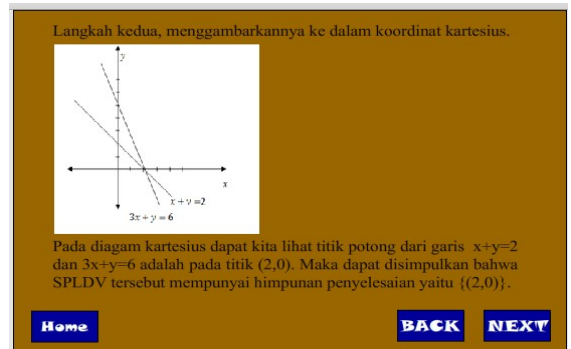

Gambar 2. Contoh ketidaksesuaian isi sekaligus tampilan

Secara lebih detail, skor rata-rata untuk masing-masing kriteria dapat dilihat dalam Tabel 2.berikut.

Tabel 2. Deskripsi kemampuan memanfaatkan teknologi pada media Power Point dan Adobe Flash

\begin{tabular}{l|l|c|c}
\hline Komponen & Kriteria & $\begin{array}{c}\text { Power } \\
\text { Point }\end{array}$ & $\begin{array}{c}\text { Adobe } \\
\text { flash }\end{array}$ \\
\hline \multirow{2}{*}{ Teknis } & Reliabilitas & 83,07 & 76,25 \\
\cline { 2 - 4 } & $\begin{array}{l}\text { Tampian } \\
\text { Desain }\end{array}$ & 77,84 & 71,50 \\
\cline { 2 - 4 } & $\begin{array}{l}\text { Kemudahan } \\
\text { Penggunaan }\end{array}$ & 78,10 & 76,12 \\
\hline \multirow{2}{*}{ Materi } & Isi & 74,49 & 74,58 \\
\cline { 2 - 4 } & Bahasa & 74,03 & 74,27 \\
\hline
\end{tabular}

Pada tabel di atas dapat diperoleh bahwa perbedaan kemampuan memanfaatkan teknologi komputer calon pendidik disebabkan oleh segi teknis yaitu berkaitan dengan pengoperasian dan pemanfaatan berbagai macam tools/fitur/aplikasi yang ada dalam program Power Point maupun Adobe Flash. Adobe flash dapat dikatakan merupakan salah satu program yang tidak mudah dipelajari dan mempunyai beberapa keterbatasn. Berkaitan dengan masalah teknis, Adobe Flash mempunyai beberapa keterbatasan yaitu menunya tidak user friendly, memerlukan banyak referensi tutorial untuk menggunakannya, kurang dalam 3D (pembuatan animasi 3D cukup sulit), bahasa pemrogrammannya agak susah, dan kurang simple (Andriyanto, 2012: 13).

Dari hasil kuesioner setelah melalui proses reduksi data diperoleh bahwa kebanyakan mahasiswa calon pendidik merasa mempunyai kemampuan yang standar/cukup memadai dalam membuat dan mengembangkan multimedia pembelajaran matematika. Mahasiswa memberikan penilaian terhadap kemampuan memanfaatkan teknologi komputer cukup beragam dan tidak sama dengan kriteria dalam tabel pengkategorian rata-rata. Hal ini disebabkan karena kurang telitinya peneliti di mana peneliti tidak memberikan alternatif jawaban yang sesuai dengan kelima kategori. Namun demikian, tersirat bahwa mahasiswa calon pendidik merasa sudah mempunyai kemampuan yang memadai dalam memanfaatkan teknologi untuk mengembangkan multimedia pembelajaran matematika. Secara lebih detail persentase hasil penilaian mahasiswa calon pendidik terhadap kemampuannya sendiri dalam 
Kemampuan Calon Pendidik dalam Memanfaatkan Teknologi Komputer untuk Mengembangkan Multimedia Pembelajaran Matematika

Niluh Sulistyani

memanfaatkan teknologi komputer dapat video, dan (5) kebingungan dalam

dilihat dalam diagram di bawah ini.

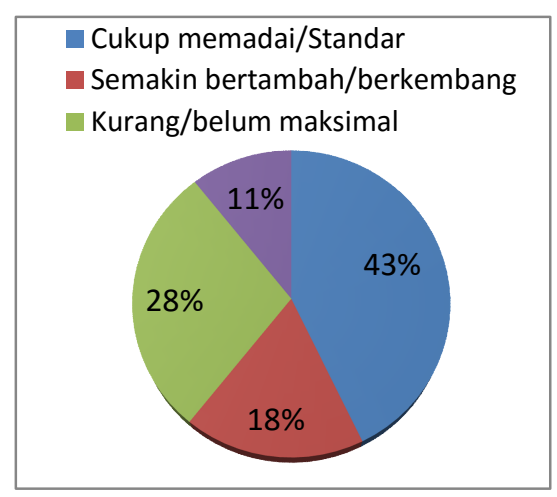

Gambar 2. Persentase kemampuan memanfaatkan teknologi dari hasil kuesioner $\begin{array}{rrr}\text { Walapun } & \text { secara } & \text { tersurat tidak } \\ \text { menyebutkan } & \text { bahwa } & \text { kemampuan }\end{array}$ memanfatkan teknologi sudah baik namun pada dasarnya kemampuan memanfaatkan teknologi calon pendidik bertambah. Lebih dari separuh mahasiswa meberikan penilaian yang baik atas kemampuan yang dimilikinya. Namun demikian, masih ada $18 \%$ dari total mahasiswa calon pendidik merasa tidak mahir dan sekedar paham. Alasan yang menyebabkan kemampuan tersebut adalah (1) mahasiswa kurang membaca/berlatih, (2) belum pernah memanfaatkan/menggunakan program tersebut terutama Adobe Flash, (3) masih kurang dalam mengeksplorasi fitur/aplikasi yang sesuai dengan tingkat berpikir siswa, (4) masih kesulitan dalam menyisipkan memperbaiki kesalahan dalam visual basic pada Power point/tween pada Adobe Flash.

Dari triangulasi kedua instrumen yang digunakan dapat diperoleh bahwa mahasiswa calon pendidik mempunyai kemampuan memanfaatkan teknologi yang cukup memadai dalam mengembangkan multimedia pembelajaran. Namun demikian kemampuan tersebut dapat semakin berkembang secara lebih optimal jika banyak berlatih dengan waktu yang cukup memadai sehingga mempunyai banyak kesempatan untuk lebih mengekspolasi fitur/aplikasi yang ada.

\section{KESIMPULAN}

Dari hasil penelitian yang sudah dipaparkan dapat diperoleh kesimpulan bahwa bahwa mahasiswa calon pendidik mempunyai kemampuan memanfaatkan teknologi yang cukup memadai untuk mengembangkan multimedia pembelajaran matematika. Rata-rata kemampuan mahasiswa calon pendidik dalam memanfaatkan teknologi komputer dalam kategori baik, di mana rata-rata skor yang diperoleh adalah 77,59 untuk media Power Point dan 74,54 untuk Adobe Flash. Dari analisis produk multimedia dan kuesioner diketahui bahwa kemampuan tersebut belum maksimal karena masih banyak tools yang 
belum dimanfaatkan terutama dalam Adobe

Flash. Belum terbiasanya dalam menggunakan juga menjadi salah satu faktor yang mempengaruhi kemampuan calon pendidik dalam memanfaatkan teknologi komputer.

\section{REFERENSI}

Andayani, S., dkk. 2007. Upaya Peningkatan Kemampuan Mahasiswa dalam Penguasaan Teknologi Pembelajaran melalui Tugas Pembuatan Media Berbasis Komputer dalam Perkuliahan Pemrograman Komputer. Diunduh di http://staff.uny.ac.id, tanggal 2 Maret 2016.

Andriyanto. 2012. Pengaruh Media Pembelajaran Macromedia Flash 8,0 terhadap Hasil Belajar IPA Siswa Kelas $V$ di SD Negeri Kebumen 01 Kecamatan Banyubiru Kabupaten Semarang Semester Genap Tahun Ajaran 2011/2012.(Skripsi). Universitas Kristen Satya Wacana,Salatiga

Arikunto, S \& Jabar C.S.A. 2009. Evaluasi program pendidikan (edisi kedua). Jakarta: Bumi Aksara.

Bayram, S. \& Nous, A.P. 2004. Evolution of Educational Software Evaluation: Instructional Software Assessment. The Turkish Online Journal of Educational Technology-TOJET, April Volume 3 Issue $2 . \quad$ Diunduh di. www.tojet.net/articles/v3i2/324.pdf, tanggal 10 Oktober 2016.

Mulyanta \& Leong. 2013. Tutorial Membangun Media Interaktif:Media Pembelajaran. Yogyakarta :Universitas Atmajaya.
Munir. 2015. Multimedia: Konsep \& Aplikasi dalam Pendidikan. Bandung: Alfabeta

Sadiman, A. S, dkk. 2009. Media Pendidikan : Pengertian, Pengembangan, dan Pemanfaatannya. PT RajaGrafindo Persada: Jakarta

Undang-Undang No.14 Tahun 2005. Guru dan Dosen. Diunduh di ://sindiker.dikti.go.id, tanggal 20 Januari 2016. 